\title{
REPORT
}

\section{Mesoscale regulation comes from the bottom-up: intertidal interactions between consumers and upwelling}

Karina J. Nielsen ${ }^{1 *}$ and Sergio A. Navarrete ${ }^{2}$

${ }^{1}$ Sonoma State University, Department of Biology, Rohnert Park, CA 94928, USA

${ }^{2}$ Pontificia Universidad Católica de Chile, Estación Costera de Investigaciones Marinas and Center for Advanced Studies in Ecology and Biodiversity,

Santiago, Chile

*Correspondence: E-mail: karina.nielsen@sonoma.edu

\begin{abstract}
Theory suggests that variation in resource supply should propagate up trophic webs influencing plant-herbivore interactions and abundances. Community regulation models have been tested in several ecosystems, but benthic marine ecologists have largely overlooked bottom-up factors except at the largest spatial scales. We used naturally occurring variation in nutrient supply associated with upwelling intensity (over 10s of kilometre) to test community regulation models. Higher upwelling intensity was strongly associated with increased abundance of late-successional, corticated algae, which in turn had apparent negative effects on ephemeral algae. Corticated algae were resistant to extant levels of herbivory. As a result, corticated algae were more abundant at sites of high upwelling intensity, while ephemeral algae were more abundant at sites of low upwelling intensity. We speculate that human removal of large grazers that can feed on corticated algae may interact with natural variation in nutrient supply to shift community structure over mesoscales.
\end{abstract}

\section{Keywords}

Macroalgae, upwelling, herbivory, Chile, rocky intertidal, food web, bottom-up, nutrients, functional groups, community regulation.

Ecology Letters (2004) 7: 31-41

\section{INTRODUCTION}

Resource supply rates have a strong influence on the diversity and abundance of primary producers in terrestrial, freshwater and marine ecosystems, but the scales and conditions under which they produce variability in structure and dynamics of the entire community is a matter of intensive research. In some systems, bottom-up factors propagate up the food web to indirectly control patterns of abundance at high trophic levels, while in others, bottom-up effects are difficult to detect. While the role of primary resources in structuring communities has long been emphasized in terrestrial and freshwater systems (Carpenter et al. 2001; Loreau et al. 2001; Urabe et al. 2002; Dyer \& Letourneau 2003; Schmitz 2003), benthic marine ecologists have largely considered nutrients to have only minor if any effects on community variability at all but the largest (regional, continental) spatial scales (Menge 1992). The predominant top-down view of community regulation in marine benthic habitats has been strengthened by the relative ease of manipulating consumers in these systems
(Robles \& Desharnais 2002), and at least in part by a misconception about the scales over which nutrients vary along open coasts (Menge 1992; Menge et al. 2002). Recent empirical work in a few places around the world is starting to challenge this view and shows that bottom-up processes can be an important source of variation over scales from few to 10 s of kilometres (Menge et al. 1997a,b, 2002; Nielsen 2003). Aside from the logistic limitations of directly manipulating processes occurring over large areas, the intensive collecting by humans of marine algae, herbivores and carnivores (Botsford et al. 1997; Castilla 1999; Jackson et al. 2001), makes it difficult to demonstrate and quantify the signal of bottom-up processes in coastal habitats. Indeed, coastal eutrophication and collecting of marine organisms occurs against a background of changing oceanic productivity, making it urgent to understand how these factors interact in human-influenced ecosystems (Castilla \& Duran 1985; Bustamante et al. 1995b; Menge et al. 1997a; Connolly \& Roughgarden 1998; Castilla 1999; Menge 2000; Jackson et al. 2001; Nielsen 2003). 
In marine ecosystems, nutrient supply is influenced by variation in oceanographic regimes. Local-scale experiments simulating variation in nutrient loading have shown that both nutrients and the abundance of herbivores strongly influence the structure of macroalgal assemblages (Nielsen 2001, 2003; Worm et al. 2002). Observational studies have also suggested that the abundance of algal functional groups over mesoscales (sites separated by $10 \mathrm{~s}$ of kilometres) is modified by proximity to upwelling centres where nutrients are higher (Broitman et al. 2001). Others have shown that macroalgal availability can influence the abundance of herbivores and the strength of plant-herbivore interactions (Bustamante et al. 1995a; Wootton et al. 1996). In summary, there is substantial evidence suggesting that natural variation in nutrient supply might be an important source of variation in marine plant-herbivore interactions on rocky shores, but few studies have attempted to experimentally test this proposition (but see Menge et al. 1999; Menge 2000).

Here, we use a comparative experimental approach to build upon this research and test whether natural variation in nutrient availability produced by coastal upwelling influences algal growth and succession, and whether this in turn can produce variation in herbivore assemblages and the intensity of herbivory. Our experiments were done in the Humboldt Current upwelling ecosystem, which shares many broad oceanographic characteristics with upwelling ecosystems of the north-eastern Pacific and South Africa (Longhurst 1998; Strub et al. 1998).

In eastern-boundary upwelling ecosystems, the main source of along-shore variation in surface temperature and nutrient availability is related to topographical mesoscale variability in the intensity or frequency of upwelling (Menge et al. 1997a; Longhurst 1998; Strub et al. 1998; Narváez et al. in press). Therefore, we established comparative field experiments, at four sites along the coast of central Chile that differed in upwelling intensity. Specifically, we predicted that at sites near centres of upwelling, algal growth rates would be greater, and that in the absence of herbivores, algal biomass would be greater than at sites distant from upwelling centres. Assuming that higher-order predators other than humans have negligible effects on herbivores [a reasonable assumption in Chilean intertidal communities (Santelices 1990; Fernández et al. 2000)], we predicted that herbivore size and overall biomass would be higher where algal growth rates are greater. These predictions are consistent with simple food chain models of community structure (i.e. Oksanen $e t$ al. 1981). Note that individual size and number of individuals determine herbivore biomass, and since the latter is largely controlled by recruitment from the plankton, it is possible that only average size and not overall biomass correlates positively with algal growth. Average size may also be indirectly influenced by recruitment by altering the intensity of competition among herbivores (Schmitt 1993).

\section{MATERIALS AND METHODS}

\section{Oceanographic context and intertidal community structure}

The open coast of central Chile is characterized by seasonal, wind-driven upwelling that brings cold, nutrient-rich subsurface waters to the surface near the coast. Nearshore hydrographical conditions in this region have been recently described (Broitman et al. 2001; Poulin et al. 2002a,b; Kaplan et al. 2003; Wieters et al. 2003; Narváez et al. in press). Briefly, during active upwelling produced by the intensification of southerly winds in spring and early summer, large spatial variation in sea surface temperature (SST) is observed along the coast, which is evident in AVHRR satellite images and in situ SST records (Fig. 1a). Upwelling events typically last from 3 to 10 days (Strub et al. 1998; Narváez et al. in press). Areas of colder water nearshore correspond to localized centres of newly upwelled, nutrient-rich waters, and warmer areas occur downstream from upwelling centres or within upwelling shadows (sensu Graham \& Largier 1997). As water is advected away from the upwelling centres, nutrients are depleted by photosynthetic activity, resulting in generally higher chlorophyll concentration and lower nutrients in warmer waters (Wilkerson \& Dugdale 1987; Wieters et al. 2003).

Patterns of zonation, species composition and taxonomic authorities at sites in central Chile have been described by Santelices (1990); Hoffman \& Santelices (1997); Fernández et al. (2000), and Broitman et al. (2001). Briefly, a mosaic of chthamaloid barnacles and ephemeral algae, mostly Porphyra and Enteromorpha, dominates the high zone. Beds of the mussel Perumytilus purpuratus typically dominate the midzone. Growing in patches among the mussel beds, or directly on the mussel shells, the corticated red alga Mazzaella laminarioides forms a characteristic belt. Common mid zone invertebrate grazers include juveniles of the heavily collected keyhole limpet, Fissurella crassa, as well as several abundant non-exploited species including the limpets Siphonaria lessoni and Scurria spp., and the chiton Chiton granosus. Mid-zone predators include recruits and juveniles of the heavily collected gastropod Concholepas concholepas and Acanthocyclus crabs, which feed mostly on sessile invertebrates, and birds, which feed on sessile invertebrates and limpets (Navarrete \& Castilla 2003). The sea star, Heliaster belianthus, is more common in the lower shore, but it also forages in the mid-zone. The large brown algae Lessonia nigrescens and Durvillaea antarctica fringe the low zone.

Collecting of invertebrates and algae by humans occurs at all accessible sites in central Chile. Fissurellid limpets are the 
Figure 1 Upwelling regimes, nutrient loading and location of field sites. (a) AVHRR satellite image of sea surface temperature from 19 December 1999 showing location of field sites (note distinct cold water features associated with the locations of known upwelling centres described in text). (b) Relationship between onshore water temperature and nitrate + nitrite concentration (nitrate + nitrite $\quad$ concentration $=78.00$ 4.45 (temperature) $r^{2}=0.61, P<0.0001$, $n=23)$. (c) In situ water temperature showing characteristic summer upwelling events. (d) Cross-correlation analysis of daily in situ temperature records (each site is crosscorrelated with Matanzas); dashed lines are \pm 2 SE of the time series; legend as in (c).

\section{(a)}

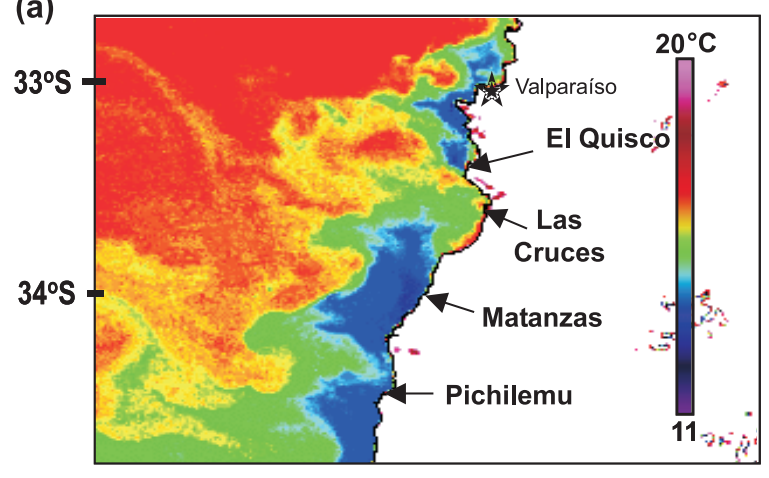

(b)

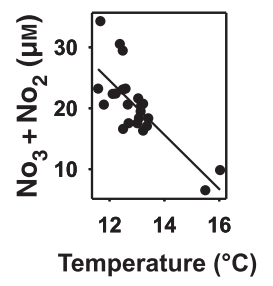

(c)
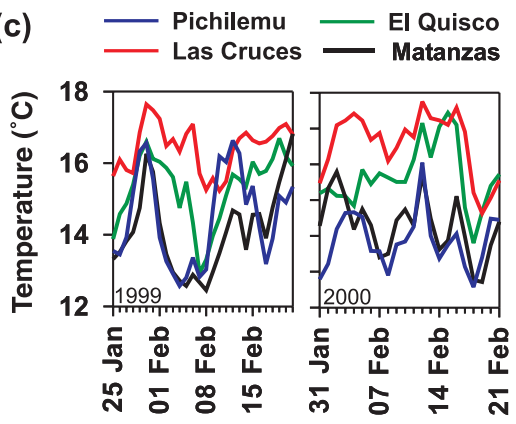

(d)

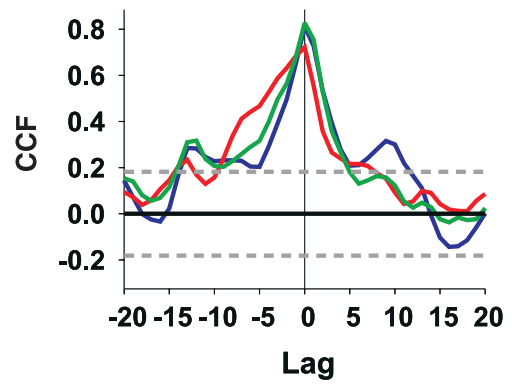

most commonly collected intertidal invertebrates in the midintertidal zone (Castilla 1999), while Concholepas are collected mostly from the low shore. The red alga $M$. laminarioides is also collected at some sites.

\section{Sites for experimental manipulations}

We selected mid-intertidal rocky benches of similar orientation and wave-exposure at four sites that differed in their position relative to upwelling centres and, therefore, nutrient availability. Our southern most sites, Pichilemu $\left(34^{\circ} 26^{\prime} \mathrm{S}\right.$ and $\left.72^{\circ} 03^{\prime} \mathrm{W}\right)$ and Matanzas $\left(33^{\circ} 58^{\prime} \mathrm{S}\right.$ and $\left.71^{\circ} 53^{\prime} \mathrm{W}\right)$, are located near centres of active upwelling at Punta Roncura (Arcos \& Salamanca 1984) and Punta Toro (Fonseca \& Farias 1987; Strub et al. 1998; Thomas 1999), respectively (Fig. 1a). Our two northern sites, Las Cruces $\left(33^{\circ} 30^{\prime} \mathrm{S}\right.$ and $\left.71^{\circ} 39^{\prime} \mathrm{W}\right)$ and $\mathrm{El}$ Quisco $\left(33^{\circ} 24^{\prime} \mathrm{S}\right.$ and $\left.71^{\circ} 42^{\prime} \mathrm{W}\right)$, are located at the northern end and to the north, respectively, of the Bay of Cartagena (Fig. 1a). The site at Las Cruces appears to be rarely directly affected by upwelling and is thought to lie in an 'upwelling shadow' (Wieters et al. 2003; Narváez et al. in press), while newly upwelled waters occur at El Quisco only during prolonged, intense southerly winds (Poulin et al. 2002b; Narváez et al. in press). Thus, we classified Pichilemu and Matanzas as sites with higher nutrient loading near shore and strong offshore advection, and Las Cruces and El Quisco as sites distant from upwelling centres, only intermittently bathed by newly upwelled water, and therefore with lower nutrient inputs.
These a priori classifications were further evaluated by physical measurements taken during the course of the study. Temperature loggers (StowAway ${ }^{\circledR}$ TidbiTs, Onset Computers Corp., Bourne, MA, with $\pm 0.2^{\circ} \mathrm{C}$ precision) were deployed at c. $1 \mathrm{~m}$ depth and logged temperatures every $10 \mathrm{~min}$ at all four sites. To corroborate the relationship between temperature and nutrients (nitrates and nitrites), water samples were collected from the shore and analysed following standard methods (Wheeler 1985).

\section{Algal growth rates}

To evaluate the effect of differences in nutrient availability on algal growth of the dominant mid-intertidal species, we conducted algal transplant experiments to all sites between February 1999 and March 2000. Small, non-reproductive individuals (fronds $c .1 \mathrm{~cm}$ long and initial wet weight $c .1 \mathrm{~g}$ ) of $M$. laminarioides growing atop mussels ( $P$. purpuratus) were collected from a common source population at Pelancura (located in between northern and southern study sites) and, after dissecting out the mussels tissue, the shells were glued to small numbered pieces of Plexiglas ${ }^{\circledR}$ (Rohm, Germany). The entire assembly weighed $c .15 \mathrm{~g}$, changes in mass ranged from $c .0 .2$ to $4 \mathrm{~g}$ for samples that did not lose mass as a result of bleaching (see Results). Surface moisture was removed prior to weighing and damaged plates were not used. Weights were determined on a scale with a precision of 0.001 g. Each trial consisted of 25 plates installed at haphazardly selected locations within the Mazzaella zone at each site. Plates were 
held above the rock surface on $5 \mathrm{~cm}$ PVC tubes and painted with copper anti-fouling paint to deter herbivores. Trials were run for 6-8 weeks, during which time we typically lost about 5-10 replicates. Monthly growth rates were calculated from the change in mass over time.

To assess whether differences in growth rates result in among-site differences in plant size, we also measured the maximum size of established plants of Mazzaella at each site. Due to high variation in frond size within individual algal clumps (Santelices et al. 2003), we measured the length of the longest blade in each of 100-210 clumps along a $30 \mathrm{~m}$ long transect through the middle of the Marzaella belt.

\section{Algal-herbivore interactions}

To determine whether herbivores had differential effects on algal abundance and biomass, we conducted the same replicated herbivore exclusion experiments at all study sites. We haphazardly chose fifteen $25 \times 25 \mathrm{~cm}$ plots within the mid-zone where Mazzaella was present. Since nearby algal stands and therefore algal recolonization tends to be patchy, experimental plots were grouped to form five blocks, usually set up on separate benches. Three treatments were then randomly allocated to plots within each block: (1) Control, in which herbivores were allowed unimpeded access to plots and the corners of the plot were marked with screws, (2) herbivore exclusion treatment, in which all herbivores were excluded, and (3) manipulation control, in which herbivores were allowed access to plots, but plots had partial barriers on three sides. To exclude grazers, we used a copper anti-fouling paint applied on a band of epoxy putty around the experimental plots, and a barrier of plastic scrub brushes bolted to the rock (bristles upward) immediately outside the epoxy putty border. The brushes were necessary to exclude keyhole limpets, which were not deterred by copper paint. The paint did impede the access of other limpets and chitons. Partial barriers in manipulation controls were discontinuous sections of brushes and copper paint. Between December 1998 and January 1999, plots were cleared of organisms by scraping and then 'burning' the rock with a propane torch.

The plots were monitored four times between January 1999 and February 2000 using a $15 \times 15 \mathrm{~cm}$ divided quadrat to make visual estimates of percentage cover of all sessile organisms (Dethier et al. 1993). All mobile organisms within the quadrat were counted and removed as necessary. Algal abundance was quantified at the lowest taxonomic level possible (species or genus), but was pooled into functional groups (Steneck \& Dethier 1994; Broitman et al. 2001; Nielsen 2003) for analyses. After the experiment was terminated, all algae in the plots were removed and weighed to determine algal biomass.
To assess potential responses of herbivores to variability in algal abundance or productivity, we measured densities and sizes of mobile invertebrates using two or three $0.25 \mathrm{~m}^{2}$ quadrats placed within c. $0.25 \mathrm{~m}$ of experimental plots. Surveys were conducted three times during 1999. Small limpets were sub-sampled in a $0.04 \mathrm{~m}^{2}$ cell of the quadrat. Herbivore biomass was estimated for each species based on length to wet weight regressions obtained from separately collected individuals (S. A. Navarrete, unpublished data).

To assess the generality of our results across a broader range of sites along the coast of central Chile, we used 62 satellite images and in situ water temperature records to classify 15 sites (including our experimental sites) as exposed to either high (six sites) or low (nine sites) intensity upwelling regimes (see Broitman et al. 2001 for methods). Sites were spaced $c .0 .5^{\circ}$ apart between $29^{\circ}$ and $36^{\circ} \mathrm{S}$. During summer 2001, we surveyed the abundance (cover) of macroalgae at each rocky intertidal site by randomly positioning eight to $1050 \times 50 \mathrm{~cm}$ quadrats (with a $10 \times 10 \mathrm{~cm}$ grid) in the high and mid-intertidal zones of each of three benches separated by $100-500 \mathrm{~m}$.

\section{Data analyses}

We examined total algal biomass at the end of the herbivore experiment (described below), as well as the change in cover of the two dominant functional groups observed during the course of the study: (1) thin blades and filaments (hereafter referred to as 'ephemerals', including Ulvoids, Enteromorpha sp., Polysiphonia sp., Porphyra columbina, Petalonia fascia, Scytosiphon lomentaria, and Colpomenia phaeodactyla), and (2) corticated algae (dominated by M. laminarioides, but also Nothogenia fastigiata, Centroceras clavulatum, Adenocystis utricularis, Ceramium spp. Gelidium cbilense and G. ligulatum). A third functional group, fleshy crustose algae, was present, but since they represented a small fraction of total algal biomass in the mid-zone, we did not analyse them. Since results showed that corticated algae were nearly absent during early succession $(<5 \%)$ and started to colonize and dominate cover in the latter half of this study, we averaged the first two and last two time periods together (on a plot by plot basis) to compare responses during 'early' and 'late' successional stages. Thus there were only two time periods in the analyses of algal cover.

We used the change in macroalgal cover over time in the herbivore exclusions to test the hypothesis that macroalgal growth and biomass accumulation differed with proximity to upwelling centres. We also tested for differences in algal accumulation in the presence of ambient densities of herbivores in the control plots. We directly tested the hypothesis that herbivores had a significant effect on algal cover by analysing the difference in cover between plots with and without herbivores present (pairing the plots 
within blocks). Before calculating this difference, we tested for evidence of artefacts caused by the experimental manipulation, using the paired differences between control and manipulation control plots within each block. If there was no evidence of artefacts, we averaged control and manipulation control plots and subtracted the cover from the exclusion plot to estimate the effect of herbivory. If there was evidence of an artefact and the effect size was small, we used only the cover in the manipulation control plot, and estimated the relative effect of herbivory in the presence of an artefact. This was the case for corticated algal cover: there was a small positive effect of the experimental manipulation, so in this case, the absolute estimate of the herbivore effect may be conservative. If herbivore effects were significant, we examined the per capita herbivore effect, which was the herbivore effect divided by herbivore density.

We used a general linear mixed model (Littell et al. 1996) implemented in SAS Proc Mixed (ver. 8e) for statistical analyses because we had a combination of fixed, random and repeated measure effects (von Ende 1993; Potvin 1993). The mixed model approach extends the familiar general linear model by allowing for both correlation and heterogeneous variances, but still assumes approximate normality (Littell et al. 1996). Upwelling regime (high or low) and time (early and late succession) were modelled as fixed effects. Sites nested within upwelling regimes were modelled as random effects. Variance components of random effects were estimated using restricted maximum likelihood. We checked the distribution of the residuals visually against predicted values using normal probability plots. Corticated algal cover was $\log$ transformed $[\ln (x+1)]$ to improve distribution of residuals.

The following full statistical model was used for all comparisons:

$y=\alpha+\beta \boldsymbol{x}+\gamma(\beta) \boldsymbol{x}+\tau \boldsymbol{x}+\tau[\beta \boldsymbol{x}+\gamma(\beta) \boldsymbol{x}]+$ residual error where, $x$ is the response variable under the different conditions previously described, $\alpha$ the fitted intercept (or overall mean), $\beta$ is the upwelling effect, $\gamma$ the site effect, and $\tau$ the successional stage (time) effect. Note that the intercept in this model represents the average of the response variable in the absence of interaction with other model factors. We considered two alternate models for the covariance structure of the repeated measures: (1) compound symmetry (assumed in traditional univariate repeated measures), (2) completely unstructured (analogous to multivariate repeated measures). We compared the fit of the models using Akaike's Information Criterion and Schwarz's Baysian Criterion (Littell et al. 1996). The unstructured model gave the best fit for all response variables.

Results of the algal transplant experiments and final algal biomass were also analysed using a mixed model. Trial (for the transplant experiments only) and upwelling regime were treated as fixed factors, and site nested within upwelling regime was treated as a random factor. Trials in the transplant experiment were completely independent so repeated measures modelling was not necessary. Growth rates were $\log$ transformed to meet model assumptions.

\section{RESULTS}

\section{Hydrographical conditions}

Records of SST supported previous results, showing that during spring and summer months average daily water temperature was usually colder at Matanzas $($ mean $=13.6 \pm 0.295 \% \mathrm{CI})$ and Pichilemu $13.8( \pm 0.2)$ than at El Quisco $14.6( \pm 0.2)$ and Las Cruces 15.9 ( \pm 0.2$)$. During an upwelling event, average daily temperature at upwelling centres could vary as much as $3.8^{\circ}$ over a 4 day period, while over the same period the change in SST could be as little as $1.1^{\circ}$ at Las Cruces (Fig. 1c.) During winter months, water temperatures were colder and less variable both within and among sites $\left(13.7-14.7^{\circ} \mathrm{C}\right)$. Upwelling events were more pronounced and of longer duration at high upwelling sites (Fig. 1c). As expected, there was a significant inverse relationship between water temperature and nitrate + nitrite concentration (Fig. 1b). Differences in the pattern of cross-correlations among sites support qualitative patterns visually assessed in the time series of satellite images and the in situ temperature records (Fig. 1d). Cross-correlations revealed that water temperatures are strongly and positively correlated among sites, but with varying time lags. Temperature at the upwelling centres of Matanzas and Pichilemu were highly correlated only at short-time lags ( $<3$ days), while Las Cruces and Matanzas were correlated with lags of up to $c .7$ days (Fig. 1d). This is consistent with temperature drops at Las Cruces being produced by water upwelled downstream and advected toward that site (Wieters et al. 2003; Narváez et al. in press). Note that despite its latitudinal position, El Quisco showed intermediate patterns of cross-correlation (Fig. 1d).

\section{Algal growth rates}

The growth rate of $M$. laminarioides varied among trials and with upwelling regime (mixed model: trial $P=0.0107$, $F=3.93$, d.f. $=3,100$; upwelling $P=0.0002, F=22.88$, d.f. $=1,15.8)$. Growth rates were reduced by $60 \%$ during summer relative to late winter and spring. We also observed extensive bleaching of intertidal macroalgae at all sites during summer months when low mid-day tides coincided with calm sea conditions. Mazzaella growth rates were 2.5 times greater at high upwelling sites. Average growth rates in $\mathrm{g} \mathrm{month}^{-1}( \pm 95 \% \mathrm{CI})$ were $0.40( \pm 0.20)$ and 
$0.41( \pm 0.13)$ at Matanzas and Pichilemu, respectively, and $0.16( \pm 0.06)$ and $0.17( \pm 0.09)$ at El Quisco and Las Cruces, respectively. The differences in growth patterns from the transplant experiments were also reflected in maximum blade sizes observed in natural stands in spring 1999. Maximum blade sizes (cm) averaged ( $\pm 95 \%$ CI $) 11.0$ ( \pm 0.6$)$ and $10.9( \pm 0.8)$ at Matanzas and Pichilemu, respectively, and $7.3( \pm 0.6)$ and $6.6( \pm 0.5)$ at El Quisco and Las Cruces, respectively.

\section{Algal-herbivore interactions}

During early succession, ephemeral algal cover was greater than $60 \%$ in the absence of herbivores and less than $20 \%$ in their presence (Fig. 2a,b), but did not differ between upwelling regimes (Fig. 2a,b, Table 1). The total effect of herbivory on ephemerals remained constant throughout the experiment and did not differ with upwelling regime (mixed model estimate $=-42.2 \pm 11.2(\mathrm{SE}), P=0.0087$; all interaction terms $P>0.15)$. In contrast, the per capita effect of herbivores on ephemeral algal cover was 2.6 times greater near upwelling centres (mixed model, upwelling effect: high $-9.5 \pm 1.7$ (SE) vs. low $-3.7 \pm 1.7, P=0.0328, F=5.84$, d.f. $=1,11.8)$. Where herbivores had been excluded, ephemeral algal cover changed sharply over time, declining by $26 \%$ at high upwelling sites but increasing by $31 \%$ at low upwelling sites (Fig. 2a, Table 1).
Corticated algae (mostly Mazzaella) were scarce at all sites during early succession, and there were no differences between upwelling regimes (Table 1). In later successional stages, corticated algae exponentially increased in abundance (16-fold) at sites adjacent to upwelling centres, but remained low or even declined at sites of low upwelling intensity (Fig. 2c,d). Herbivores had no effect on corticated algal cover at any time during the course of the experiment (mixed model herbivore effect and all interactions $P>0.24$; Fig. 2c,d).

The striking differences in algal composition associated with upwelling conditions at the end of the experiment translated into large differences in total algal biomass between upwelling regimes (Fig. 2e); algal biomass was seven times greater near upwelling centres. Herbivore effects on total algal biomass were evident only at low upwelling sites, where ephemeral algae were more abundant (Fig. 2d,e).

Total density and biomass of herbivores was greater at sites of low upwelling intensity (Fig. 3). These patterns were driven primarily by the abundance of the small limpets S. lessoni and Scurria spp. (Fig. 3a), which are not collected by humans. The abundance of chitons (also not collected) did not differ among sites. The heavily exploited keyhole limpet, F. crassa, was consistently low in abundance (Fig. 3a) and small in size at all sites. Collisella parasitica although relatively abundant occurs almost exclusively on mussels (its

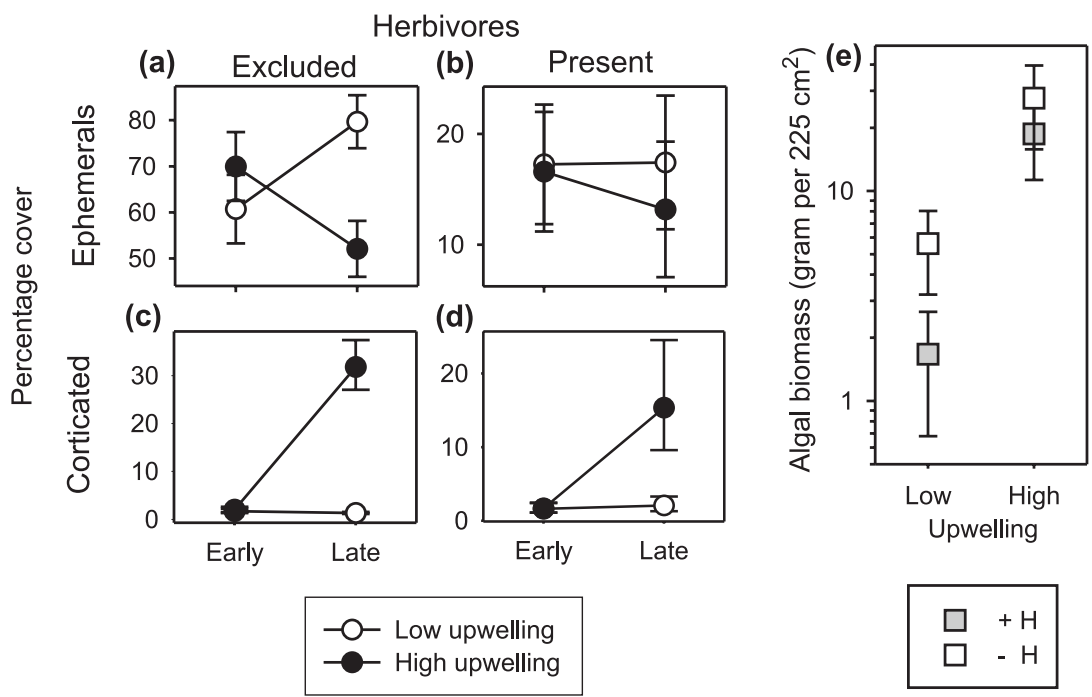

Figure 2 Effects of upwelling and herbivory on algal cover and biomass. Algal cover at sites located immediately adjacent to upwelling centres are denoted by 'high' to reflect the higher nutrient loading and offshore advection experienced at these sites relative to those sites distant from upwelling centres and denoted by 'low.' Successional stage is denoted by 'early' and 'late' (first and last 6 months, respectively) of the experiment (see Methods for details). The data plotted are the least square means $( \pm \mathrm{SE})$ from the linear mixed model. Ephemeral algae with herbivores (a) excluded and (b) present. Corticated algae with herbivores (c) excluded and (d) present; mean valuess and SE were back transformed from log to linear scale. (e) Algal biomass (average $\pm 95 \% \mathrm{CI}$ ) at the termination of the experiment. Herbivores present $=+\mathrm{H}$, herbivores excluded $=-\mathrm{H}$, Low and High as in (a). 
Table 1 Mixed linear model analysis of algal cover

\begin{tabular}{|c|c|c|c|c|c|c|}
\hline \multirow{2}{*}{$\frac{\text { Algal cover }}{\text { Ephemeral }}$} & \multicolumn{3}{|c|}{ Herbivores excluded } & \multicolumn{3}{|c|}{ Herbivores present } \\
\hline & & & & & & \\
\hline & d.f. & $F$ & $P$-value & d.f. & $F$ & $P$-value \\
\hline \multicolumn{7}{|l|}{ Fixed effects } \\
\hline Upwell & 17.8 & 2.09 & 0.1656 & 2.24 & 0.10 & 0.7813 \\
\hline Stage & 17.8 & 0.01 & 0.9398 & 17 & 0.59 & 0.4537 \\
\hline \multirow[t]{2}{*}{ Upwell $\times$ stage } & 17.8 & 6.73 & 0.0184 & 17 & 0.72 & 0.4080 \\
\hline & Estimate & SE & $P$-value & Estimate & SE & $P$-value \\
\hline \multicolumn{7}{|l|}{ Random effects } \\
\hline Site (upwell) & 0 & - & - & 14.84 & 60.5 & 0.4013 \\
\hline Site $\times$ stage $($ upwell $)$ & 0 & - & - & 0 & - & - \\
\hline \multicolumn{7}{|l|}{ Corticated } \\
\hline & d.f. & $F$ & $P$-value & d.f. & $F$ & $P$-value \\
\hline \multicolumn{7}{|l|}{ Fixed effects } \\
\hline Upwell & 8.44 & 42.3 & 0.0001 & 2.5 & 2.97 & 0.2011 \\
\hline Stage & 3.2 & 48.29 & 0.0050 & 17 & 54.75 & $<0.0001$ \\
\hline \multirow[t]{2}{*}{ Upwell $\times$ stage } & 3.2 & 69.88 & 0.0028 & 17 & 35.05 & $<0.0001$ \\
\hline & Estimate & SE & $P$-value & Estimate & SE & $P$-value \\
\hline \multicolumn{7}{|l|}{ Random effects } \\
\hline Site (upwell) & 0 & - & - & 0.251 & 0.3102 & 0.2092 \\
\hline Site $\times$ stage $($ upwell $)$ & 0.002689 & 0.05852 & 0.4817 & 0 & - & - \\
\hline
\end{tabular}

Bold values are significant at $\alpha=0.05$. abundance is correlated with mussel cover) and probably did not influence algal abundance in the experimental plots.

\section{Large scale community surveys}

There were large and opposite differences in the abundance of ephemeral and corticated macroalgae among sites that varied in upwelling intensity (Fig. 4). While corticated algae were significantly more abundant at sites of high upwelling intensity, regardless of tidal level (Fig. 4a,b; corticated macroalgae: two-way ANOVA for upwelling effect $P=0.0002, F=19.17$, d.f. $=1,25$, and no significant upwelling $\times$ level interaction, $P=0.3295, \quad F=0.99$, d.f. $=1,25)$, ephemeral algae were more abundant at sites of low upwelling intensity, although differences were nonsignificant (Fig. 4a,c; two-way ANOvA, $P=0.0650$, $F=3.73$, d.f. $=1,25$, and no significant upwelling $\times$ level interaction, $P=0.6663, F=0.19$, d.f. $=1,25)$. Previous studies considering a larger number of sites (Broitman et al. 2001) have found the same pattern and significant differences in both functional groups. The pattern of algal abundance is thus qualitatively similar to those observed in the comparative experiments described above (Figs 2 and 4).

\section{DISCUSSION}

Our results show that the intensity of upwelling can leave a clear, yet complex signal in the structure of intertidal communities in central Chile (Fig. 5). The effects of bottomup forcing at sites of high upwelling intensity could not be predicted from simple food-chain models of community regulation (Fig. 5). Increased nutrients were strongly associated with positive effects on growth of herbivore-resistant corticated algae but with negative effects on ephemeral algae. The herbivore assemblage in this human-exploited intertidal system had a negative effect on ephemeral algae only. As a result, corticated algal abundance was higher at sites of high upwelling intensity, regardless of herbivore treatment. In contrast, ephemeral algae and herbivore biomass were higher at sites of low upwelling intensity. These effects appear to be general, influencing intertidal zone community structure across 15 sites, spanning $7^{\circ}$ of latitude $(c .900 \mathrm{~km})$ along the coast of central Chile. Upwelling regime was clearly associated with differences in the structure and successional trajectories of algal assemblages, but these effects were not evident until the latter half of the experiment (after c. 6 months), consistent with previous work suggesting that bottom-up influences develop slowly relative to top-down effects in intertidal systems (Nielsen 2003). As observed in other studies, ephemeral algae (mostly ulvoids) were the first to colonize the cleared plots at all sites, regardless of the intensity of upwelling. In these initial stages, herbivores readily reduced ephemeral algae to less than one-third the cover in herbivore exclusion plots. Differences in herbivore density and biomass between high and low upwelling areas did not generate differences in the total effect of herbivory, 


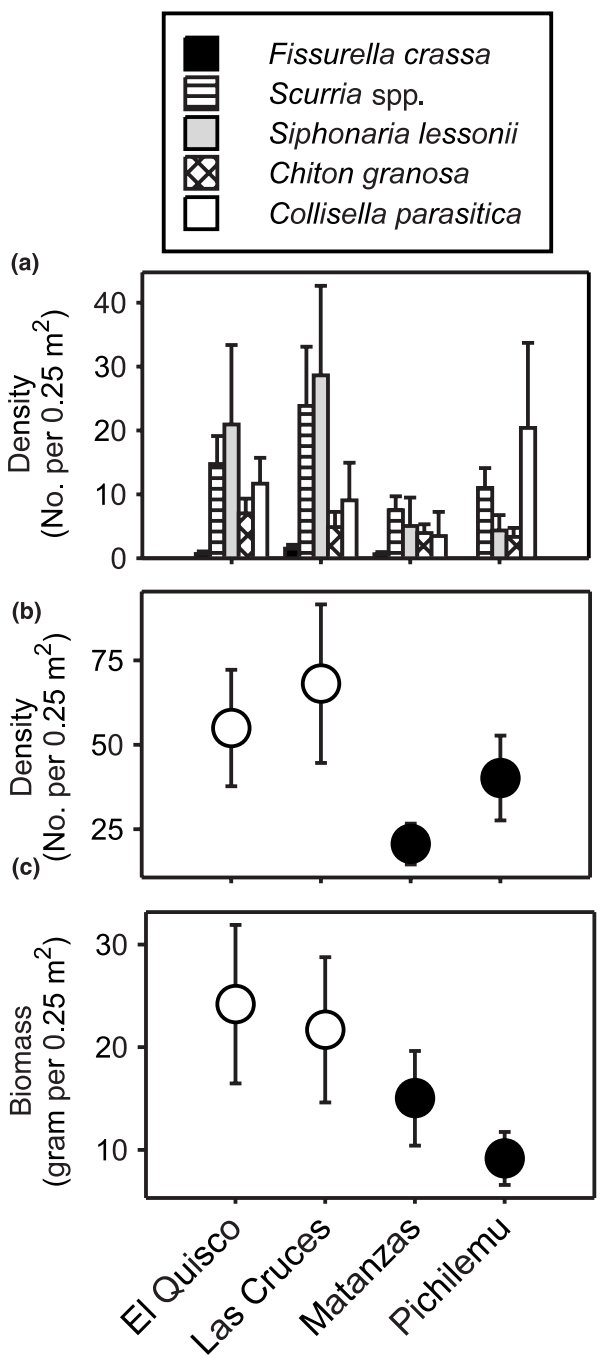

Figure 3 Mid-intertidal zone herbivore abundances. (a) Average density $(+95 \% \mathrm{CI})$ of the five major groups of invertebrate herbivores at each site over three survey periods. (b) Total density of all herbivores combined (average $\pm 95 \%$ CI), filled circles $=$ high upwelling intensity, open circles $=$ low upwelling intensity; and (c) total herbivore biomass (average $\pm 95 \% \mathrm{CI}$ ) symbols as in (b).

but per capita effects of herbivores did vary across upwelling intensity.

Two mechanisms may be at work to lower herbivore abundances at high upwelling sites: (1) recruitment of juveniles from the plankton may be reduced due to more persistent offshore advection of surface waters during upwelling (e.g. Gaines et al. 1985; Connolly \& Roughgarden 1998; Connolly et al. 2001); or (2) food for herbivores may have been limiting since ephemeral algal abundance was lower at these sites, and these herbivores consume primarily ephemeral epilithic algae (Santelices et al. 1986). Mazzaella often formed a short canopy at the high upwelling sites, with small herbivores congregating near the holdfasts. Higher per capita effects may have been the result of ameliorated microscale physical conditions (i.e. temperature and desiccation) for herbivores during low tide under fronds of Mazzaella, facilitating longer periods of grazing at sites where Mazzaella was more abundant. Further studies are needed to distinguish among these possibilities.

In later successional stages, corticated algae colonized the plots at all sites, but grew 16 times faster at sites of high upwelling intensity, out-growing and apparently out-competing ephemeral algae. We hypothesize that similar interactions may occur within patches of the mussel bed at larger spatial scales yielding a similar inverse abundance pattern at regional spatial scales (Figs 2 and 4). However, more work is needed to understand the interaction between these two functional groups and with sessile invertebrates. Because corticated macroalgae dominated total algal biomass at upwelling sites, and were not affected by herbivores, there was no herbivore effect on total algal biomass at these sites.

Keyhole limpets, which are larger in the absence of human exploitation (Moreno 2001), have strong negative effects on Mazzaella (Iridaea) inside marine reserves in southern Chile (Mehuín 39²4'S, Jara \& Moreno 1984) and in central Chile (Las Cruces, Oliva \& Castilla 1986). At our sites, although juvenile Fissurella were present, the dominant herbivores were the small limpets Scurria spp., Siphonaria, and chitons, which negatively affected only ephemerals. Thus, lack of herbivore effects on later successional stages could be an indirect consequence of humans collecting large keyhole limpets. Although humans strongly impact the abundance of large individuals (Jara \& Moreno 1984; Oliva \& Castilla 1986), juvenile abundances are similar inside and outside reserves (Castilla 1999), and this was reflected in the similarly low biomass of $F$. crassa at all of our sites (Fig. 3). This result is consistent with experiments by Jara \& Moreno (1984), and agrees well with patterns of abundance of major functional groups across larger spatial scales.

The shore-based measurements of water temperature and nitrate concentrations support the a priori designation of sites as high and low upwelling regimes, and support findings from other studies conducted in the area (e.g. Broitman et al. 2001; Wieters et al. 2003; Narváez et al. in press). At Pichilemu and Matanzas, waters were overall colder and more variable on synoptic time scales, during the austral spring-summer upwelling season, indicating that these areas respond quickly to wind stress forcing. Warmer, more nutrient-depleted waters were observed at sites of low upwelling intensity, but conditions at El Quisco were intermediate relative to Las Cruces, despite its geographical position at the extreme of the experimental sites. The differences between these last two sites probably reflect the 'upwelling shadow' located in Las Cruces (Wieters et al. 2003). 
Figure 4 Intertidal algal cover in mid- and high-zones at 15 sites (between 29 and $36^{\circ} \mathrm{S}$ ) along the coast of Chile. (a) Satellite sea surface temperature (SST) image from 14 November 1992 showing location of sites and classification with respect to upwelling regime; black arrows = high upwelling and white arrows = low upwelling. Average percentage cover $( \pm \mathrm{SE}$ ) of (b) corticated and (c) ephemeral algae.
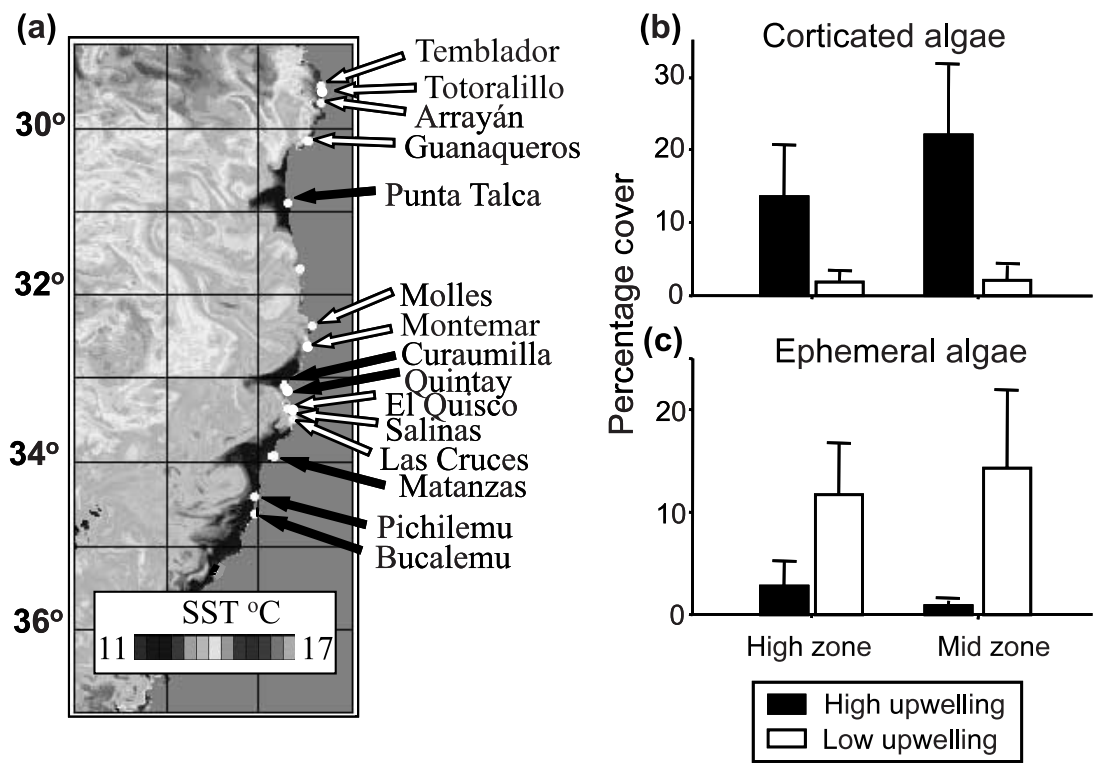

Because one of the goals of this study was to examine natural variation in nutrient supply at larger spatial scales, we did not directly manipulate nutrients and other factors may have co-varied with upwelling. For example, aerial temperatures and humidity during low tide might have been more conducive to algal growth at high upwelling sites if the colder waters consistently promoted the generation of coastal fog. Subtle differences in tidal height among sites may have also contributed. Our observations during the course of the study suggest that fog or other aerial conditions were not likely causative factors. There is no apparent positive correlation between upwelling and fog. If any differences, Las Cruces tended to be foggier than our other sites, while persistently windy conditions at Matanzas often resulted in algae drying to a crisp during low tides. Since we used biological zones rather than absolute tidal heights, placing our experiments within the middle of the intertidal distribution of Mazzaella, slight differences in wave run-up and immersion times should have been diminished. Moreover, independent measurements of wave forces and water flow have shown no differences among these sites (S.A. Navarrete and R. Finke, unpublished data). Finally, the analysis of our larger scale survey including sites of different upwelling intensity interspersed from north to south (Fig. 4a) and two tidal heights (mid and high) is consistent with the interpretation of a nutrient effect, not a latitudinal effect.

\section{CONCLUSIONS}

Oceanographic bottom-up effects clearly influence intertidal community structure, but are not easily predicted from models of community regulation, generating interactions webs that vary over space (Fig. 5). At high upwelling sites, corticated algae grow faster, attain higher biomass, apparently suppress ephemerals, and herbivores play minor roles. At low upwelling sites, corticated algal growth is reduced and herbivores become increasingly important in the community by controlling the abundance of ephemerals and attain higher biomasses. There are few sites along the Chilean coastline that are inaccessible to humans, and we observed heavy collecting at all our sites. Selective removal of large keyhole limpets by humans could reduce grazing pressure on corticated algae. These results highlight the importance examining both bottom-up and top-down effects in naturally variable and human-exploited ecosystems. We suggest that if large keyhole limpets are rare because of human collecting, then humans are indirectly modifying community regulation at varying rates over mesoscales, depending on the intensity of upwelling.

\section{ACKNOWLEDGEMENTS}

We thank B. Menge, E. Wieters, S. Hacker and three anonymous reviewers for their helpful comments, and all the 'ECIMianos' for assistance and camaraderie. We are grateful for funding provided by NSF grant INT 9802715 to K.J.N., Fondecyt no. 1971263 and FONDAP-Fondecyt 1501-0001 to the Center for Advanced Studies in Ecology and Biodiversity to S.A.N., and an Andrew W. Mellon Foundation grant to S.A.N. and Juan Carlos Castilla. This is contribution number 146 of the Partnership for Interdisciplinary Studies of Coastal Oceans (PISCO): A Long-Term Ecological Consortium funded by the David and Lucile Packard Foundation. 


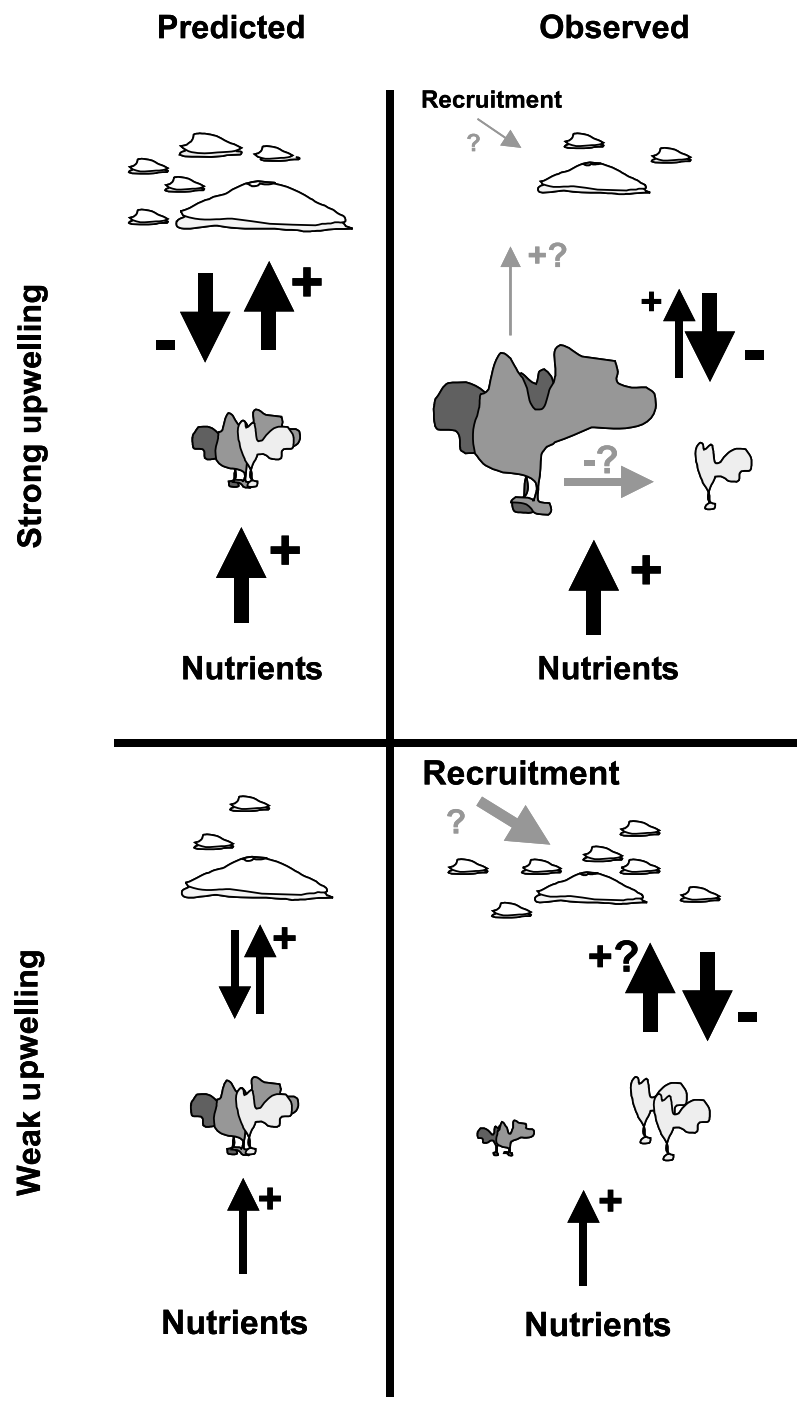

Figure 5 Predicted and observed interaction webs. Thickness of the arrows and size of the lettering reflect interaction strengths. Grey arrows and question marks indicate hypothesized, but yet to be tested interactions. Predicted interaction web is based on a food chain model of community regulation. Observed interaction web depicts the results of the experiments. The lightest coloured algal fronds represent ephemeral algae, the darker ones represent corticated algae. Herbivores are represented by the limpets and fissurellids at the top of the food chain.

\section{REFERENCES}

Arcos, D.F. \& Salamanca, M.A. (1984). Distribucion de clorofila y condiciones oceanograficas frente a Chile central (latitudes $32^{\circ} \mathrm{S}-38^{\circ} \mathrm{S}$, Febrero 1982). Biologia Pesquera, 13, 5-14.

Botsford, L.W., Castilla, J.C. \& Peterson C.H. (1997). The management of fisheries and marine ecosystems. Science, 277, 509-514.

Broitman, B.R., Navarrete, S.A., Smith, F. \& Gaines, S.D. (2001). Geographic variation of southeastern Pacific intertidal communities. Marine Ecol.-Progr. Ser., 224, 21-34.
Bustamante, R.H., Branch, G.M. \& Eekhout, S. (1995a). Maintenance of an exceptional intertidal grazer biomass in South Africa: subsidy by subtidal kelps. Ecology, 76, 2314-2329.

Bustamante, R.H., Branch, G.M., Eekhout, S., Robertson, B., Zoutendyk, P., Schleyer, M. et al. (1995b). Gradients of intertidal primary productivity around the coast of South Africa and their relationships with consumer biomass. Oecologia, 102, 189-201.

Carpenter, S.R., Cole, J.J., Hodgson, J.R., Kitchell, J.F., Pace, M.L., Bade, D. et al. (2001). Trophic cascades, nutrients, and lake productivity: whole-lake experiments. Ecol. Monogr., 71, 163-186.

Castilla, J.C. (1999). Coastal marine communities: trends and perspectives from human-exclusion experiments. Trends Ecol. Evol., 14, 280-283.

Castilla, J.C. \& Duran, L.R. (1985). Human exclusion from the rocky intertidal zone of central Chile: the effects on Concholepas concholepas (Gastropoda). Oikos, 45, 391-399.

Connolly, S.R. \& Roughgarden, J. (1998). A latitudinal gradient in Northeast Pacific intertidal community structure: evidence for an oceanographically based synthesis of marine community theory. Am. Nat., 151, 313-326.

Connolly, S.R., Menge, B.A. \& Roughgarden, J. (2001). A latitudinal gradient in recruitment of intertidal invertebrates in the northeast Pacific Ocean. Ecology, 82, 1799-1813.

Dethier, M.N., Graham, E.S., Cohen, S. \& Tear, L.M. (1993). Visual versus random-point percent cover estimations: 'objective' is not always better. Mar. Ecol. Progr. Ser., 96, 93-100.

Dyer, L.A. \& Letourneau, D. (2003). Top-down and bottom-up diversity cascades in detrital vs. living food web. Ecol. Lett., 5, 60-68.

von Ende, C.N. (1993). Repeated-measures analysis: growth and other time-dependent measures. In: Design and Analysis of Ecological Experiments (eds Scheiner, S.M. \& Gurevitch, J.). Chapman and Hall, New York, pp. 113-137.

Fernández, M., Jaramillo, E., Marquet, P.A., Moreno, C.A., Navarrete, S.A., Ojeda, F.P. et al. (2000), Diversity, ecology and biogeography of nearshore benthic ecosystems: an overview and needs for conservation. Revista Chilena de Historia Natural, 73, 629-662.

Fonseca, T.R. \& Farias, M. (1987). Estudio del proceso de surgencia en la costa de Chile utilizando percepcion remota. Invest. Pesq., 34, 33-46.

Gaines, S., Brown, S. \& Roughgarden, J. (1985). Spatial variation in larval concentration as a cause of spatial variation in settlement for the barnacle, Balanus glandula. Oecologia, 67, 267-272.

Graham, W.M. \& Largier, J.L. (1997). Upwelling shadows as nearshore retention sites: the example of northern Monterey Bay. Continental Shelf Res., 17, 509-532.

Hoffman, A. \& Santelices, B. (1997). Flora Marina de Chile Central. Ediciones Universidad Católica de Chile, Santiago, Chile.

Jackson, J.B.C., Kirby, M.X., Berger, W.H., Bjorndal, K.A., Botsford,L.W., Bourque, B.J. et al. (2001). Historical overfishing and the recent collapse of coastal ecosystems. Science, 293, 629-638.

Jara, H.F. \& Moreno, C.A. (1984). Herbivory and structure in midlittoral rocky community a case in southern Chile. Ecology, 65, 28-38.

Kaplan, D.M., Largier, J., Navarrete, S.A., Guiñez, R. \& Castilla, J.C. (2003). Large diurnal temperature fluctuations in the nearshore water column. Estuarine, Coastal Shelf Sci., 57, 385-398.

Littell, R.C., Milliken, G.A., Stroup, W.W. \& Wolfinger, R.D. (1996). SAS System for Mixed Models. SAS Institute Inc., Cary, NC. 
Longhurst, A. (1998). Ecological Geography of the Sea. Academic Press, San Diego.

Loreau, M., Naeem, S., Inchausti, J., Bengtsson, J., Grime, J.P., Hector, A. et al. (2001). Biodiversity and ecosystem functioning: current knowledge and future challenges. Science, 294, 804-808.

Menge, B.A. (1992). Community regulation: under what conditions are bottom-up factors important on rocky shores? Ecology, 73, $755-765$.

Menge, B.A. (2000). Top-down and bottom-up community regulation in marine rocky intertidal habitats. J. Exp. Mar. Biol. Ecol., 250, 257-289.

Menge, B.A., Daley, B.A., Wheeler, P.A., Dahlhoff, Sanford, E. \& Strub, P.T. (1997a). Benthic-pelagic links and rocky intertidal communities: bottom-up effects on top-down control? Proc. Natl Acad. Sci., 94, 14530-14535.

Menge, B.A., Daley, B.A., Wheeler, P.A. \& Strub, P.T. (1997b). Rocky intertidal oceanography: an association between community structure and nearshore phytoplankton concentration. Limnol. Oceanogr., 42, 57-66.

Menge, B.A., Daley, B.A., Lubchenco, J., Sanford, E., Dahlhoff, E., Halpin, P.M. et al. (1999). Top-down and bottom-up regulation of New Zealand rocky intertidal communities. Ecol. Monogr., 69, 297-330.

Menge, B.A., Sanford, E., Daley, B.A., Freidenburg, T.L., Hudson, G. \& Lubchenco, J. (2002). Inter-hemispheric comparison of bottom-up effects on community structure: Insights revealed using the comparative-experimental approach. Ecol. Res., 17, 1-16.

Moreno, C.A. (2001). Community patterns generated by human harvesting on Chilean shores: a review. Aquatic Conserv-Mar. Freshwater Ecosyst., 11, 19-30.

Narváez, D., Poulin, E., Leiva, G., Hernández, E., Castilla, J.C. \& Navarrete, S.A. (in press). Spatial variation of nearshore oceanographic conditions in central Chile. Continental Shelf Res.

Navarrete, S.A. \& Castilla, J.C. (2003). Experimental determination of predation intensity in an intertidal predator guild: dominant versus subordinate prey. Oikos, 100, 251-262.

Nielsen, K.J. (2001). Bottom-up and top-down forces in tidepools: test of a food-chain model in an intertidal community. Ecol. Monogr., 71, 187-217.

Nielsen, K.J. (2003). Nutrient loading and consumers: agents of change in open-coast macrophyte assemblages. Proc. Natl Acad. Sci., 100, 7660-7665.

Oksanen, L., Fretwell, S.D., Arruda, J. \& Niemela, P. (1981). Exploitation ecosystems in gradients of primary productivity. Am. Nat., 118, 240-261.

Oliva, D. \& Castilla, J.C. (1986). The effect of human exclusion on the population structure of key-hole limpets Fissurella crassa and F. limbata on the coast of central Chile. Pubblicazioni della Stazione Zoologica di Napoli I: Mar. Ecol., 7, 201-217.

Potvin, C. (1993). ANOVA: Experiments in controlled environments. In: Design and Analysis of Ecological Experiments (eds Scheiner, S.M. \& Gurevitch, J.). Chapman \& Hall, New York, pp. 46-68.

Poulin, E., Palma, A.T., Leiva, G., Hernandez, E., Martinez, P., Navarrete, S.A. et al. (2002a). Temporal and spatial variation in the distribution of epineustonic competent larvae of Concholepas concholepas along the central coast of Chile. Mar. Ecol.Progr. Ser., 229, 95-104.

Poulin, E., Palma, A.T., Leiva, G., Narvaez, D., Pacheco, R., Navarrete, S.A. et al. (2002b). Avoiding offshore transport of competent larvae during upwelling events: The case of the gastropod Concholepas concholepas in Central Chile. Limnol. Oceanogr., 47, 1248-1255.

Robles, C. \& Desharnais, R. (2002). History and current development of a paradigm of predation in rocky intertidal communities. Ecology, 83, 1521-1536.

Santelices, B. (1990). Patterns of organizations of intertidal and shallow subtidal vegetation in wave exposed habitats of central Chile. Hydrobiologia, 192, 35-57.

Santelices, B., Vasquez, J. \& Meneses, I. (1986). Patrones de distribucion y dietas de un gremio de moluscos herbivoros en habitats intermareales expuestos de Chile central. Monografías Biológicas, 4, 147-171.

Santelices, B., Aedo, D., Hormazabal, M. \& Flores, V. (2003). Field testing of inter- and intraspecific coalescence among mid-intertidal red algae. Mar. Ecol.-Progr. Ser., 250, 91-103.

Schmitt, R.J. (1993). Geographic variation in population characteristics of an intertidal gastropod: demographic differences or settlement history? In: Third California Islands Symposium: Recent Advances in Research on the California Islands (ed. Hochberg, F.G.). Santa Barbara Museum of Natural History, Santa Barbara, pp. 257-271.

Schmitz, O.J. (2003). Top predator control of plant biodiversity and productivity in an old-field ecosystem. Ecol. Lett., 6, 156-163.

Steneck, R.S. \& Dethier, M.N. (1994). A functional group approach to the structure of algal-dominated communities. Oikos, 69, 476-498.

Strub, P.T., Mesias, J.M., Montecino, V., Rutllant, J. \& Salinas, S. (1998). Coastal ocean circulation off Western South America coastal segment (6,E). The Sea, 11, 273-313.

Thomas, A.C. (1999). Seasonal distributions of satellite-measured phytoplankton pigment concentration along the Chilean coast. J. Geophys. Res. - Oceans, 104, 25877-25890.

Urabe, J, Elser, J.J., Kyle, M., Yoshida, T., Sekino, T. \& Zenichiro, K. (2002) Herbivorous animals can mitigate unfavourable ratios of energy and material supplies by enhancing nutrient recycling. Ecol. Lett., 5, 177-185.

Wheeler, P.J. (1985). Nutrients. In: Ecological Field Methods: Macroalgae (eds Littler, M.M. \& Littler, D.S.). Cambridge University Press, Cambridge, pp. 53-64.

Wieters, E.A., Kaplan, D.M., Navarrete, S.A., Sotomayor, A., Largier, J., Nielsen, K.J. et al. (2003). Spatial and temporal variability in chlorophyll a concentration in Chilean nearshore waters. Mar. Ecol. Progr. Ser., 249, 93-105.

Wilkerson, F.P. \& Dugdale, R.C. (1987). The use of large shipboard barrels and drifters to study the effects of coastal upwelling on phytoplankton dynamics. Limnol. Oceanogr., 32, 368-382.

Wootton, J.T., Power, M.E., Paine, R.T. \& Pfister, C.A. (1996). Effects of productivity, consumers, competitors, and El Niño events on food chain patterns in a rocky intertidal community. Proc. Natl Acad. Sci., 93, 13855-13858.

Worm, B., Lotze, H.K., Hillebrand, H. \& Sommer, U. (2002). Consumer versus resource control of species diversity and ecosystem functioning. Nature, 417, 848-851.

Editor, S. D. Hacker

Manuscript received 1 July 2003

First decision made 23 July 2003

Second decision made 18 September 2003

Manuscript accepted 16 October 2003 